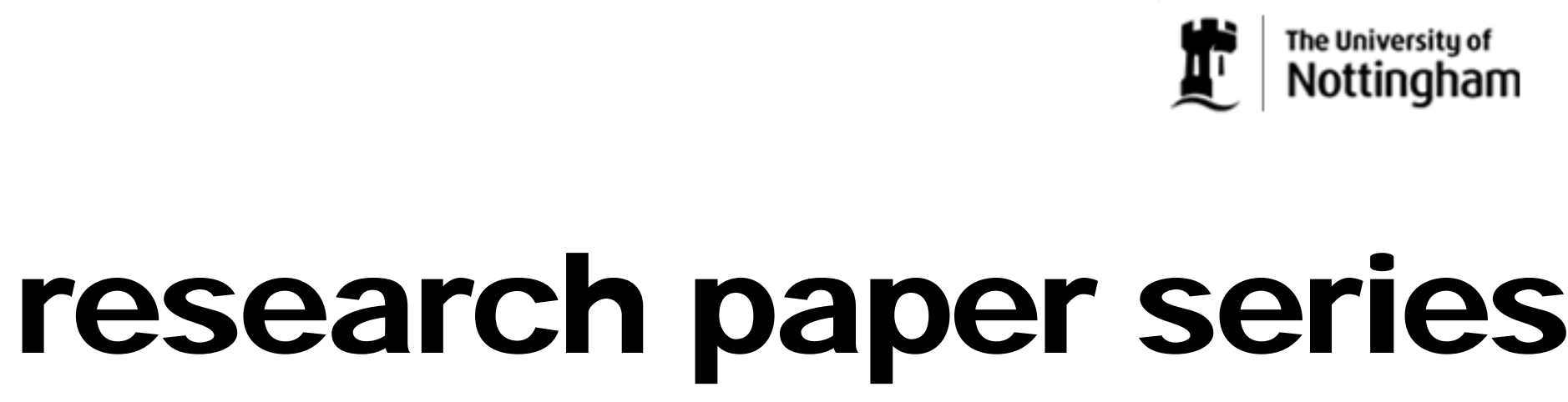

Globalisation and Labour Markets

Research Paper 2007/24

Does offshoring reduce industry employment?

by

Alexander Hijzen and Paul Swaim 


\section{The Authors}

Alexander Hijzen is an Economist at the OECD and a Research Fellow in GEP and Paul Swaim is a Senior Economist in the OECD.

\section{Acknowledgements}

This research was conducted as part of the OECD project on Globalisation and Structural Adjustment III. The present paper is an extension to the analysis of offshoring that was published in Chapter 3 of the OECD Employment Outlook 2007 "OECD workers in the global economy: increasingly vulnerable?”. The authors would like to thank Sébastien Martin for excellent research assistance. The authors are also grateful to Andrea Bassanini, Sven Blondal, Boris Cournede, Martine Durand, Sam Hill, Molly Lesher, John Martin, Nigel Pain and Raymond Torres for very helpful comments and suggestions on an earlier draft. The opinions expressed in this paper are those of the authors and do not necessarily reflect those of the OECD or its member states. All remaining errors are our own. This paper is forthcoming in the National Institute Economic Review as part of a symposium on "Technology, Jobs and Skills".

Address for correspondance: 2 rue André-Pascal, 75775 Paris Cedex 16, France. Email: alexander.hijzen@oecd.org. 


\title{
Does offshoring reduce industry employment?
}

by

Alexander Hijzen and Paul Swaim

\begin{abstract}
This paper looks at the implications of offshoring for industry employment whilst explicitly accounting for the scale and technology effects of offshoring. The effects of offshoring on employment are analysed using industry-level data for 17 high income OECD countries. Our findings indicate that offshoring has no effect or a slight positive effect on sectoral employment. Offshoring within the same industry ("intra-industry offshoring") reduces the labour-intensity of production, but does not affect overall industry employment. Inter-industry offshoring does not affect labour-intensity, but may have a positive effect on overall industry employment. These findings suggest that the productivity gains from offshoring are sufficiently large that the jobs created by higher sales completely offset the jobs lost by relocating certain production stages to foreign production sites.
\end{abstract}

\section{JEL classification: F16}

Keywords: international outsourcing, labour demand.

\section{Outline}

1. Introduction

2. Data and trends

3. A first look

4. Econometric methodology

5. Results

6. Sensitivity analysis

7. Concluding remarks 


\section{Non-Technical Summary}

In recent years, offshoring has become one of the most controversial economic issues in the public debate because of its alleged, its implications for workers, and in particular, for their jobs. It is often felt that whilst offshoring leads to important gains to producers and consumers, the costs appear to fall disproportionately on workers, especially those with low levels of skills.

This paper looks at the implications of offshoring for workers in terms of their employment opportunities at the sectoral level. In the present paper offshoring refers to the relocation abroad of tasks that were previously performed at home and the products of which are subsequently shipped back home in the form of imported intermediate inputs. Classical examples of offshoring include the manufacture of apparel and toys in China and the production of car components in Taiwan.

An important element of the analysis is to explicitly account for the 'relocation' (or 'technology') effect and the scale effect of offshoring. The relocation effect reflects the destruction of jobs that occurs when firms relocate part of their production activities overseas. By contrast, the scale effect captures the creation of jobs following the expansion in industry output that may arise as a result of the productivity gains from offshoring. In this paper we analyse the employment effects of offshoring at the sectoral level using data for 17 high income OECD countries.

Our findings indicate that offshoring has no effect or a slight positive effect on sectoral employment. More specifically, our results indicate that while offshoring within the same industry ("intra-industry offshoring") reduces the labour-intensity of production, it does not affect overall industry employment. Inter-industry offshoring does not affect labour-intensity, but may have a positive effect on overall industry employment. These findings suggest that the productivity gains from offshoring are sufficiently large that the jobs created by higher sales completely offset the jobs lost by relocating certain production stages to foreign production sites.

Even if offshoring typically does not result in net employment losses at the level of the industry or even the firm, this does not necessarily mean that workers do not encounter significant adjustment difficulties. For example, previous work shows that intra-industry offshoring is associated with increasing skill demands, suggesting that some of the workers whose jobs are lost due to the technology effect from offshoring may lack the qualifications required by the jobs created by the scale effect.

Finally, the offshoring data for 1995 and 2000, which are used in this study, may understate the future impact of offshoring on the sectoral and occupational composition of employment. As many have observed, advances in information and communications technologies appear to be greatly expanding the range of service activities that could be relocated to foreign production sites. It is therefore worth noting that even should offshoring come to have important implications for industry-level labour demand, this still would not imply a reduction in the total number of jobs in the economy. In this case, offshoring, like trade in final goods, would be a force for structural adjustment along the lines implied by the principle of comparative advantage. 


\section{Introduction}

In recent years, offshoring has become one of the most controversial economic issues in the public debate. This is clearly illustrated by the flurry in the U.S. media that followed the publication of the Economic Report of the President in February 2004 (Mankiw and Swagel, 2006). Another example is the French no-vote in the referendum on the EU Constitution, which according to the Eurobarometer opinion poll, reflects to an important extent concerns about job loss due to the relocation of production to low-wage countries (European Commission, 2005). While offshoring represents no doubt one of the main distinguishing characteristics of the current stage of globalisation, its implications for workers, and in particular, for their jobs, are subject to considerable controversy. It is often felt that whilst offshoring leads to important gains to producers and consumers, the costs appear to fall disproportionately on workers, especially those with low levels of skills.

This paper looks at the implications of offshoring for workers in terms of their employment opportunities at the sectoral level. In the present paper offshoring refers to the relocation abroad of tasks that were previously performed at home and the products of which are subsequently shipped back home in the form of imported intermediate inputs. Classical examples of offshoring include the manufacture of apparel and toys in China (e.g. Toys R Us develops a toy design, the production of which is sourced to China and imported back for final packaging and marketing) and the production of car components in Taiwan.

An important element of the analysis is to explicitly account for the technology and scale effects of offshoring. The technology effect reflects the destruction of jobs that occurs when firms relocate part of their production activities overseas. By contrast, the scale effect captures the creation of jobs following the expansion in industry output that may arise as a result of the productivity gains from offshoring. ${ }^{1}$

In order to analyse the employment effects of offshoring in a first step, we propose a novel decomposition of employment that allows one to identify the scale and technology effects separately. We subsequently use this decomposition to relate changes in offshoring intensity to the scale and technology components of sectoral employment changes. In second step, we conduct a detailed econometric analysis of the scale and technology effects

1. See Olsen (2006) for a review of the literature on offshoring and productivity and Hijzen et al. (2007) for a recent case study for Japan. 
of offshoring for industry employment using sectoral data for 17 high income OECD countries.

Our findings indicate that offshoring has no effect or a slight positive effect on sectoral employment, which is broadly consistent with previous findings by Amiti and Wei (2005, 2006) for the United States. More specifically, our results indicate that while offshoring within the same industry ("intra-industry offshoring") reduces the labour-intensity of production, it does not affect overall industry employment. Inter-industry offshoring does not affect labour-intensity, but may have a positive effect on overall industry employment. These findings suggest that the productivity gains from offshoring are sufficiently large that the jobs created by higher sales completely offset the jobs lost by relocating certain production stages to foreign production sites.

The structure of this paper is as follows. Section 2 discusses data and measurement issues in relation to offshoring and describes the trend in offshoring across a number of OECD countries. Section 3 provides a first look at the possible effects of offshoring on industry employment. Section 4 sets outs the econometric methodology, while Section 5 discusses the results. Section 6 reports a number of robustness checks that were undertaken to assess the sensitivity of our core results to the exclusion of outliers and the way one controls for technological change. Finally, Section 7 concludes.

\section{Data and trends}

\subsection{Data and measurement}

Measuring offshoring is not straightforward. Typically, efforts have focussed on trade in intermediates in one way or another. The main drawback of focusing on trade in intermediates is that one necessarily excludes the offshoring of assembly activities. However, direct data on the value of offshoring are typically not available, and if they are, they are unlikely to be suitable for empirical work. In line with most previous work we will therefore also focus on trade in intermediates.

Several different data sources been used to document trade in intermediates including data on outward processing trade (similar concepts are 'foreign trade zones' or 'overseas assembly programs'), standard trade statistics and input-output tables. Data on outward 
processing trade are based on the customs arrangement in which complete tariff exemptions or partial levy reductions are granted in accordance to the domestic input content of imported goods. Outward processing trade involves the exporting of intermediate inputs for further processing abroad and the re-importing of those products back to the home country. The product classification of trade statistics can also be used to infer how much trade in intermediate goods affects the nature of world trade. For analytical purposes input-output tables are usually considered to be the most appropriate data source as they allow one to make comparisons across sectors, countries and time.

The input-output data used in this paper are obtained from the 2006 edition of the OECD's Input-Output Database. Input-output tables describe the sale and purchase relationships between producers and consumers within an economy. ${ }^{2}$ As such, they allow one to measure intermediate input purchases by each industry from each industry. The tables further distinguish between domestically supplied intermediate inputs and inputs imported from abroad via the so-called domestic-use and import-use matrices. ${ }^{3}$

Broadly speaking, we measure offshoring by focusing on the foreign content of production using the ratio of imported intermediates (using the import-use matrix) to valueadded. More specifically, we define two measures of offshoring: intra-industry and interindustry offshoring. Intra-industry offshoring ('narrow offshoring' in Feenstra and Hanson, 1999), measures the share of imported intermediate inputs from the same industry in industry value-added. ${ }^{4}$ Formally, and suppressing the country and time subscripts for simplicity, narrow offshoring $S^{N}$ for industry i is given by:

$$
S_{i}^{N}=\frac{O_{j=i}}{V_{i}}
$$

2. They can be produced by recording flows between the sales and purchases (final and intermediate) of industry outputs or by recording the sales and purchases (final and intermediate) of product outputs. The OECD Input-Output Database is presented on the former basis, which facilitates linking data with other sources, which are in the main collected by establishments, and so industry.

3. The input-output tables may differ somewhat from official country estimates due to adjustments that were made with respect to disclosure rules.

4. Feenstra and Hanson (1996) measure offshoring as the share of imported inputs in total intermediate inputs thereby emphasizing the choice between purchasing intermediate inputs at home and abroad. In the present case, we define offshoring as the share of imported intermediate inputs in value-added, which emphasizes the relocation of production activities formerly produced in the home industry. 
where $\mathrm{O}$ refers to imported intermediate purchases from industry $\mathrm{j}=\mathrm{i}$ by industry $\mathrm{i}$, and $\mathrm{V}$ to value-added. Compared to total offshoring the measure of intra-industry offshoring is likely to come closer to the essence of relocation, which tends to take place within the same industry. ${ }^{5}$ Inter-industry offshoring $S^{D}$ is defined as the ratio of imported intermediate purchases by industry $i$ from all industries $j$ other than $i$ to value added:

$$
S_{i}^{D}=\frac{\sum_{j=1}^{J} O_{j \neq i}}{V_{i}}
$$

where $\mathrm{O}$ refers to imported intermediate purchases from industry $\mathrm{j} \neq \mathrm{i}$ by industry $\mathrm{i}$ and $\mathrm{V}$ to value-added.

The input-output data are combined with sectoral production data from the OECD STAN database and data on R\&D expenditure from the OECD ANBERD dataset. As the input-output tables are only available for the years 1995 and 2000 the dataset is necessarily constrained to those two years. The dataset used for the empirical analysis of this paper includes the following countries: Australia, Austria, Belgium \& Luxembourg, Canada, Denmark, Finland, France, Germany, Greece, Italy, the Netherlands, Norway, Portugal, Spain, Sweden, the United Kingdom and the United States. The industrial classification broadly follows that used in the OECD STAN database, which is based on the International Standard Industrial Classification (ISIC), Rev 3. The agriculture and mining industries (ISIC 01-14) were excluded from the analysis. ${ }^{6}$

\subsection{Stylised facts}

There is considerable evidence that offshoring has been increasing for several decades. Campa and Goldberg (1997) document offshoring using a similar measure to that employed in the present paper. They show that this measure of offshoring rose from 4\% in 1974 to $8 \%$ in 1993 in the United States, from $16 \%$ to $20 \%$ in Canada and from $13 \%$ to $22 \%$ in the United Kingdom, but fell from $8 \%$ to $4 \%$ in Japan. Hummels et al. (2001) focus on a narrower concept, the foreign content of exports (or "vertical specialisation"), which is

5. The drawback of this measure is that it relies on the way industries are classified.

6. More precisely, in terms of ISIC Rev. 3 the following industries were included in the analysis: 15$16,17-19,20,21-22,24,25,26,27,28,29,30,31,32,33,34,35,36-37,45,50-52$; 70-71; 73-74, $55,60-63,72$. 
measured by the share of imported intermediates in exports. They find that vertical specialisation increased by $28 \%$ between 1970 and 1990 in 14 countries and that this increase accounted for $30 \%$ of total export growth for these countries.

Figure 1 presents more recent statistics for the foreign content of production for 17 OECD countries using the OECD Input-Output data for 1995 and 2000. ${ }^{7}$ The data on offshoring confirm that imported inputs constitute a prominent feature in production in OECD economies, although the degree of offshoring varies significantly across these countries. ${ }^{8}$ Between 1995 and 2000, offshoring grew in 15 out of 17 of those countries, but often by only a small amount. ${ }^{9}$

Figure 1. Offshoring in selected OECD countries, 1995 and $2000^{a}$

Share of imported intermediates in the total output (percentage)

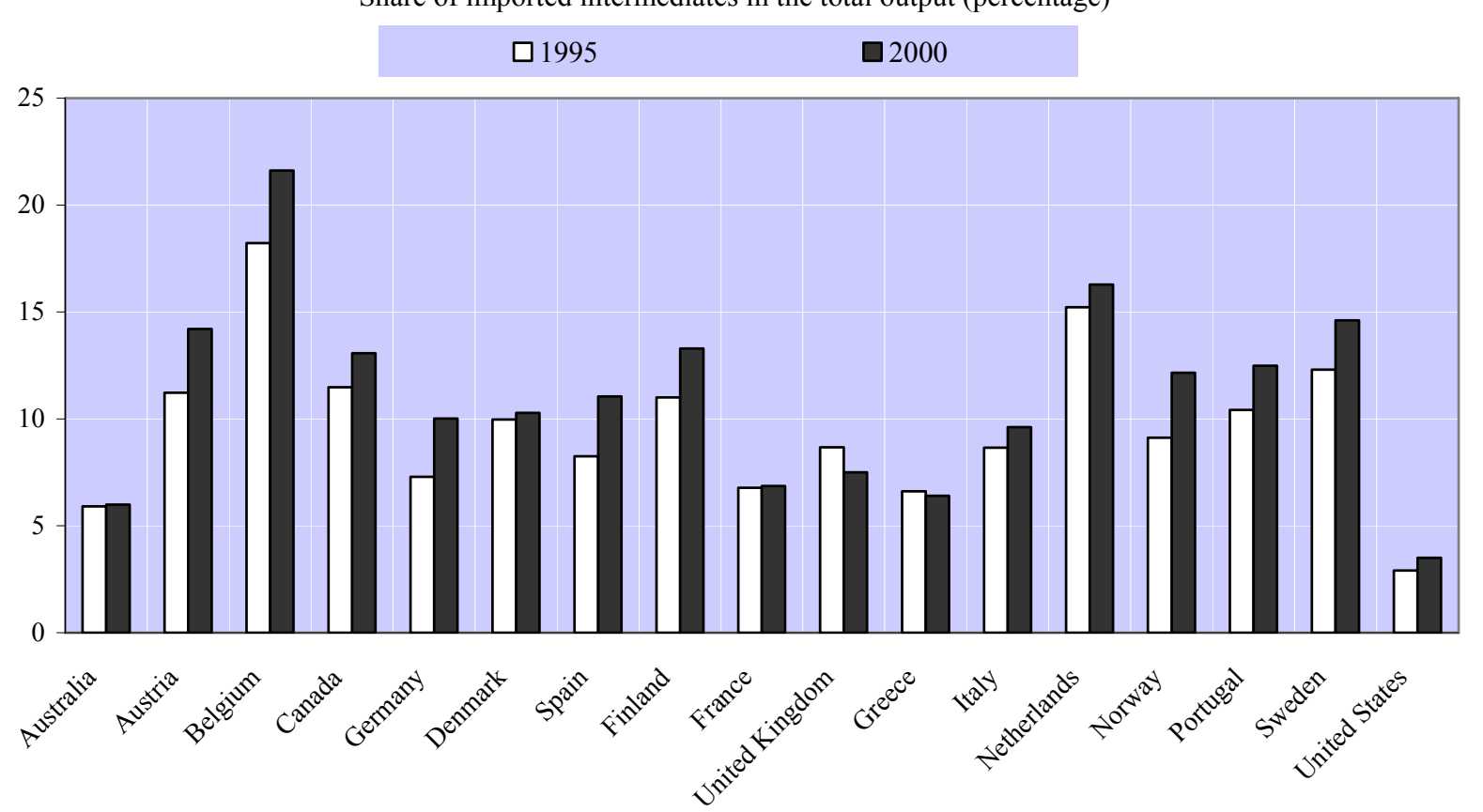

a) 1995 and 1999 for Greece and Portugal; 1997 and 2000 for Canada; and 1997 and 2001 for Norway.

Source: Author's calculations based on OECD STAN Input-Output tables.

7. The data values reported here tend to be quite a bit lower than those reported by Campa and Goldberg (1997), because the primary sector is excluded.

8. The shares of trade in intermediate goods are higher for small countries, such as Belgium and the Netherlands (respectively, $16 \%$ and $12 \%$ of GDP in 2000), than for large countries, particularly the United States $(3 \%)$. This may be due, in part, to the fact that larger countries can achieve economies of scale more easily than small countries and can thus retain more stages of production at home.

9. The scale of services offshoring to date remains quite modest, typically around at $2 \%$ of sales. However, improvements in IC technologies (e.g. the Internet) make it increasingly feasible and profitable to offshore certain service activities. The data suggest that the growth of offshoring of business services during 1995-2000 was more widespread and somewhat more rapid than the growth of material offshoring (OECD, 2007a). 


\section{A first look}

In order to analyse the employment effects of offshoring one needs to account for both its technology and its scale effect. The technology effect reflects the destruction of jobs that occurs when firms relocate part of their production activities overseas. By contrast, the scale effect captures the creation of jobs following the expansion in industry output as a result of the productivity gains from offshoring. In order to render this more explicit we propose the following decomposition of the change in sectoral employment:

$$
\Delta L=\Delta l \bar{Y}+\bar{l} \Delta Y
$$

where $L$ refers to employment in sector $i, l$ to the labour intensity $(L / Y)$, and $Y$ to gross output; bars refer to period averages. Thus, the change in sectoral employment consists of the change in labour intensity at constant output plus the change in output at constant labour intensity. Offshoring is expected to reduce the first component via its technology effect, but increase the second component through its scale effect. The total effect of offshoring is therefore ambiguous.

The relative importance of both effects however may depend on the nature of offshoring, i.e. whether intermediate inputs are imported from the same industry or from different industries. To the extent that imports from the same industry are more likely to replace to activities previously conducted in the same domestic industry than imports from other industries, one would expect intra-industry offshoring to have a more pronounced negative effect on labour-intensity than inter-industry offshoring. By contrast, there seems to be no reason for the scale effect to depend on the industry from which the intermediate inputs are purchased.

In order to get a first idea of the role of technology and scale effects Figure 2 plots the change in intra-industry and inter-industry offshoring against the change in labour-intensity and gross output. The scatter plots are generally consistent with the hypotheses set out above. In particular, both types of offshoring are associated with declining levels of labourintensity via the technology effect and positive output growth through the scale effect. Moreover, all the correlations are statistically significant at the $5 \%$ level.

The correlations provide mixed evidence that the sectoral origin of intermediate imports matters. The negative correlation between the change in intra-industry offshoring 
and the change in labour-intensity is weaker than that between inter-industry offshoring and labour intensity $(-0.21$ versus -0.60 respectively). This suggests that the technology effect of inter-industry offshoring is more pronounced than that associated with intra-industry offshoring, contrary to what one would expect. The positive correlation between intraindustry offshoring and output is also weaker than that for inter-industry offshoring, which suggests that the productivity gains associated with the latter tend to be more pronounced. However, bivariate correlations like those presented in Figure 2 do not control for other relevant industry characteristics that may obscure the scale and technology effects, especially in the case of intra-industry offshoring where within-sample variation is quite limited. Econometric analysis allows one to study the employment effects of offshoring conditional on industry characteristics and this is what we will turn to next.

Figure 2. Technology versus scale
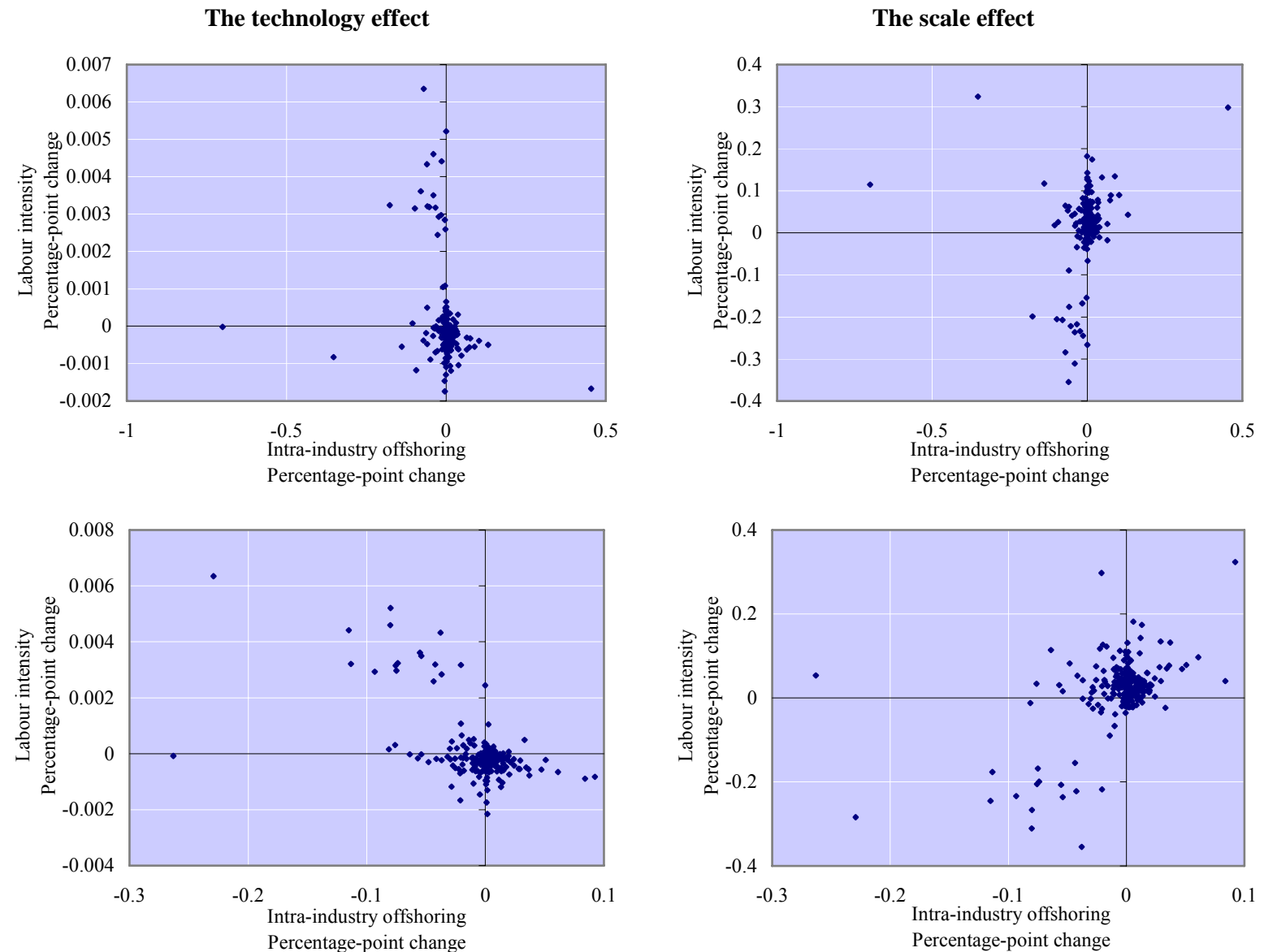

Note: Labour intensity multiplied time 1000.

Source: Author's calculations. 


\section{Econometric methodology}

In order to study the impact of offshoring on industry employment in more detail we estimate two models of labour demand: the conditional and unconditional labour-demand models. In the conditional model, the profit-maximising level of labour demand is determined by minimising the costs of production conditional on output. More specifically, industry $i$ 's production $\operatorname{costs} C_{i}\left(w_{i}, x_{i}\right)$ are a function of factor prices $w$ (for the variable factors), and output $x$. By Shephard's lemma, the partial derivatives of the cost function with respect to variable factor prices give factor demands. The conditional model of labour demand thus allows one to assess the technology effect of offshoring by keeping output constant.

In the unconditional labour-demand model, it is assumed that firms maximise profits, $\Pi_{i}\left(w_{i}, p_{i}\right)$, by choosing the optimal mix of input quantities and the level of output for given input and output prices. The profit-maximising quantity of factor demand is obtained by setting the partial derivative of profits to zero. In the case of labour demand, this corresponds to adjusting hiring so that the marginal value product of labour equals the wage. The unconditional model of labour demand thus allows one to analyse the total effect of offshoring on labour demand. The difference between the total effect and the technology effect gives an indication of the scale effect associated with offshoring.

In order to study sectoral labour demand, the log-linear model of conditional and unconditional labour demand is employed (Hamermesh, 1993). This has the advantage that the coefficients can be interpreted as elasticities. As is common in the literature, capital is treated as quasi-fixed (see for example Berman et al. (1994)). There are at least two reasons for doing so. First, this avoids measurement problems related to the user cost of capital. Second, to the extent that in the unconditional labour-demand model one may not be able to effectively control for the location of the labour demand curve, there is a risk of confounding shifts in the labour-demand schedule with changes in its slope. Including the capital stock, rather than the cost of capital, helps to control for this, while it also leaves 
some scope for changes in output. ${ }^{10}$ Omitting country and time subscripts for ease of presentation, conditional labour demand in industry $i$ is represented by:

$$
\ln L_{i}=\alpha_{o}+\sum_{j=1}^{J} \alpha_{j} \ln w_{i j}+\beta_{k} \ln k_{i}+\beta_{y} \ln y_{i}+\sum_{i=l}^{L} \gamma_{l} z_{i l}
$$

where $L$ corresponds to industry-level labour demand; $w$ to the nominal price of variable factors (i.e. the wage and the price of materials); $k$ to the capital stock and $y$ to gross output. The core model is augmented by a set of demand shifters, $z$, which are intended to capture factor-biased technological change. These include a measure for the intensity of research and development and, most importantly for this paper's analysis, intraindustry and inter-industry offshoring as discussed in Section $2 .{ }^{11}$ To the extent that R\&D leads to labor-saving innovation we would expect, an increase in R\&D intensity, like offshoring, to negatively affect labour demand, conditional on output.

Similarly, unconditional (or 'capital-constrained') labour demand in industry $i$ is represented by:

$$
\ln L_{i}=\alpha_{o}+\sum_{j=1}^{J} \alpha_{j} \ln w_{i j}+\beta_{k} \ln k_{i}+\beta_{p} \ln p_{i}+\sum_{i=l}^{L} \gamma_{l} z_{i l}
$$

where $L$ corresponds to industry-level labour demand; $w$ to the price of variable factors; $k$ to the capital stock, and $p$ to the price of gross output. As in the conditional model, the core model is augmented with a set of variables $z$, which in addition to the capital stock, are intended to control for the shifts in labour demand.

In order to empirically implement the two labour demand models we add a random error term which is assumed to be normally distributed with zero mean and constant variance. Each labour-demand model is estimated separately using 5-year differences. Differencing takes account of any time-invariant fixed effects. Long differences are used to

10. This thus represents a compromise solution between identification of the labour-demand curve and the ability to capture scale effects in the unconditional labour-demand model. As such, one may alternatively like to refer to it as the capital-constrained model.

11. Arguably, the degree of automatisation/computerisation may be a more appropriate measure of labor-saving technological change. The main reason for using R\&D intensity instead of a proxy for computerisation is the availability of comparable data across countries and time. To the extent that R\&D intensity is skill-biased rather than labour-saving its effect on total labour demand may be ambiguous. 
account for lags in the adjustment of labour demand to shocks. Moreover, estimates based on long differences are less sensitive to bias due to measurement error than either fixed effects or first-differences (Griliches and Hausman, 1986). Given the homogeneity properties of the cost and profit functions homogeneity is imposed on the empirical model. $^{12}$

\section{Results}

Table 1 presents cross-sectional estimates of the impact of offshoring on sectoral labour demand. A priori, offshoring should have a negative effect on the labour-intensity in an industry (the 'technology effect'), but a positive effect on the level of output, due to the productivity gains from offshoring (the 'scale effect'), so that the overall effect is ambiguous. The effect on labour-intensity is given by the offshoring coefficient in the conditional labour-demand estimates, while the total effect is given by the unconditional labour-demand estimates. The following results emerge:

The conditional and unconditional labour demands estimated with the cross-section data appear to be well identified. In particular, the unconditional elasticities with respect to wages (relative to the price of materials) are considerably larger than the conditional wage elasticities of labour demand, as predicted by economic theory. However, R\&D intensity does have a positive effect on labour demand in the cross-section estimates, contrary to what we did expect. This could indicate that R\&D intensity reflects merely skill-biased technological change associated with increased skilled labour demand and reduced demand for unskilled labour rather than labour-saving technological change. However, this may also be due to the high degree of correlation between this variable and the offshoring variables. As excluding R\&D might bias the coefficient on offshoring due to the presence of an omitted variable, it was decided to leave $R \& D$ intensity in the baseline regressions. However, we get back to this issue in more detail in the sensitivity analysis in the next section.

12. Clark and Freeman (1980) argue that this may aggravate bias in the estimation when measurement error is important. Standard F-tests suggest that measurement problems are unlikely to be very important here as the restriction of homogeneity could not be rejected by the data. 
The conditional demand estimates indicate that there is a significant negative correlation between offshoring within the same industry (intra-industry offshoring) and labour-intensity (employment at given output). Given the actual increase in intra-industry offshoring, the estimated coefficients imply that increased intra-industry offshoring was associated with a reduction in employment of $0.12 \%(0.19 \%$ in manufacturing) over the period 1995-2000. ${ }^{13}$ Note however that this only reflects the technology effect of offshoring. In order to evaluate the full implications of offshoring for employment one needs to refer to unconditional labour demand-estimates. There is no association between inter-industry offshoring and the labour intensity. ${ }^{14}$

The estimates for unconditional labour demand indicate that offshoring within the same industry has no impact on the level of employment. The difference between the conditional and unconditional estimates is consistent with the productivity gains from intraindustry offshoring being sufficiently large for the jobs created by higher sales to completely offset the jobs lost by relocating certain production stages to foreign production sites. Similarly, inter-industry offshoring, for which the employment losses in the offshoring industry are expected to be more limited, but the productivity gains similar, is found to increase industry-level labour demand when using the full sample. This, however, does not necessarily mean that the total effects of inter-industry offshoring are positive (or less negative) than those for intra-industry offshoring), because the present analysis does not take account of possible dis-employment effects from inter-industry offshoring spread over different sectors of the economy. That is, the labour market effects of inter-industry may tend to fall on industries other than the purchasing industry $(i \neq j)$, whereas the regressions exclusively focus on the effects in the purchasing industry (i).

13. Offshoring within the same industry increased on average in the whole economy by about 1.5 percentage points (recorded in the data as 0.015 ) over the period 1995-2000 and in manufacturing by 2 percentage points.

14. To the extent that all or some imported intermediate inputs from industries other than one's own were previously purchased from domestic suppliers, one would expect a larger coefficient for intrathan inter-industry offshoring as is also observed. Ideally, one would also like to estimate the importance of job losses that may arise when firms substitute domestic suppliers in other industries by suppliers located abroad. However, cross-industry relocation effects of this type are not estimated in this paper. 
Table 1. Baseline regression results, OLS over five-year differences

\begin{tabular}{|c|c|c|c|c|c|c|}
\hline & \multicolumn{3}{|c|}{ Conditional } & \multicolumn{3}{|c|}{ Unconditional } \\
\hline & All & Man & Ser & All & Man & Ser \\
\hline \multirow[t]{4}{*}{ log (Wage/Price of materials) } & -0.242 & - & - & - & -0.397 & -0.394 \\
\hline & & 0.222 & 0.163 & 0.420 & & \\
\hline & $(2.06)$ & $(1.62)$ & $(1.13)$ & $(4.66)$ & $(4.25)$ & $(2.87)$ \\
\hline & $* *$ & & & $* * *$ & $* * *$ & $* * *$ \\
\hline \multirow[t]{3}{*}{ log Capital stock } & 0.202 & 0.11 & 0.453 & 0.256 & 0.157 & 0.596 \\
\hline & $(2.37)$ & $(1.69)$ & $(4.63)$ & $(2.90)$ & $(2.21)$ & $(5.93)$ \\
\hline & $* *$ & $*$ & $* * *$ & $* * *$ & $* *$ & $* * *$ \\
\hline \multirow[t]{3}{*}{ log Output } & 0.18 & 0.15 & 0.364 & & & \\
\hline & $(3.91)$ & $(3.40)$ & $(3.37)$ & & & \\
\hline & $* * *$ & $* * *$ & $* * *$ & & & \\
\hline \multirow[t]{3}{*}{$\begin{array}{l}\log (\text { Price of output/Price of } \\
\text { materials) }\end{array}$} & & & & 0.326 & 0.110 & 0.415 \\
\hline & & & & $(1.35)$ & $(0.31)$ & $(2.10)$ \\
\hline & & & & & & $* *$ \\
\hline \multirow[t]{4}{*}{ R\&D intensity } & 0.500 & 0.560 & - & 0.321 & 0.243 & -0.034 \\
\hline & & & 0.052 & & & \\
\hline & $(1.85)$ & $(1.39)$ & $(0.20)$ & $(1.10)$ & $(0.49)$ & $(0.16)$ \\
\hline & $*$ & & & & & \\
\hline \multirow[t]{4}{*}{ Intra-Industry Offshoring } & -0.082 & - & - & 0.013 & -0.012 & 0.306 \\
\hline & & 0.094 & 1.096 & & & \\
\hline & $(1.85)$ & $(2.44)$ & $(0.77)$ & $(0.40)$ & $(0.38)$ & $(0.19)$ \\
\hline & $*$ & $* *$ & & & & \\
\hline \multirow[t]{4}{*}{ Inter-Industry Offshoring } & -0.034 & - & -0.64 & 0.034 & 0.023 & 0.211 \\
\hline & & 0.039 & & & & \\
\hline & $(1.19)$ & $(1.52)$ & $(1.51)$ & $(1.92)$ & $(1.11)$ & $(0.80)$ \\
\hline & & & & $*$ & & \\
\hline \multirow[t]{3}{*}{ Constant } & -0.003 & - & - & 0.000 & -0.002 & 0.001 \\
\hline & & 0.004 & 0.009 & & & \\
\hline & $(0.94)$ & $(1.21)$ & $(1.72)$ & $(0.04)$ & $(0.60)$ & $(0.24)$ \\
\hline
\end{tabular}




\begin{tabular}{l|ccc|ccc} 
& & & $*$ & & & \\
Observations & 238 & 181 & 57 & 238 & 181 & 57 \\
R-squared & 0.47 & 0.5 & 0.6 & 0.41 & 0.44 & 0.55 \\
\hline \hline
\end{tabular}

* significant at $10 \% ; * *$ significant at $5 \% ; * * *$ significant at $1 \%$, robust $t$ statistics in parentheses

\section{Sensitivity analysis}

In order to analyse the sensitivity of the results we conducted two robustness checks. First, outlier robust regressions were estimated with the help of the rreg command in STATA. This involves first excluding any outlier observations from the standard model using Cook's distance ( $>1$ ) and then iterating the model using the absolute residuals from the previous regression as weights. Second, we re-estimated the model using industry and country-specific trends instead of R\&D intensity. This reflects the desire to appropriately account for other forces towards technological change and our dissatisfaction with the role of $R \& D$ intensity in the baseline regressions. . One plausible explanation of why $R \& D$ intensity is associated with a positive or insignificant coefficient in the conditional labour demand regressions - contrary to what economic theory predicts - is that this reflects the multi-collinearity problem that arises when including R\&D and offshoring simultaneously in the regressions. As there is no direct way to address this issue country and sector-specific trends are included instead of R\&D intensity to control for technological change that occurs independent of offshoring.

The outlier robust results are reported in Table 2 . The results are very similar in nature to our baseline regressions, but generally stronger. As before, intra-industry offshoring exerts a statistically significant and negative effect on labour demand conditional on the level of output. In addition, we also find that inter-industry offshoring has a negative effect on industry employment conditional on output. Once we allow for scale effects we find that the negative effect of offshoring on employment entirely disappears. There is some indication that inter-industry offshoring raises employment in the services sector. The control variables generally have the correct sign except for $R \& D$ intensity which has a positive and significant effect on employment in most specifications. We will address this issue next. 
Table 2: Outlier robust regression results over five-year differences

\begin{tabular}{|c|c|c|c|c|c|c|}
\hline & \multicolumn{3}{|c|}{ Conditional } & \multicolumn{3}{|c|}{ Unconditional } \\
\hline & All & Man & Ser & All & Man & Ser \\
\hline \multirow[t]{4}{*}{ log (Wage/Price of materials) } & -0.124 & - & 0.006 & - & -0.422 & -0.037 \\
\hline & & 0.227 & & 0.383 & & \\
\hline & $(2.32)$ & $(3.40)$ & $(0.06)$ & $(8.06)$ & $(7.10)$ & $(0.45)$ \\
\hline & $* *$ & $* * *$ & & $* * *$ & $* * *$ & \\
\hline \multirow[t]{3}{*}{$\log$ Capital stock } & 0.145 & 0.143 & 0.253 & 0.229 & 0.201 & 0.29 \\
\hline & $(5.53)$ & $(5.03)$ & $(3.30)$ & $(8.73)$ & $(7.27)$ & $(4.53)$ \\
\hline & $* * *$ & $* * *$ & $* * *$ & $* * *$ & $* * *$ & $* * *$ \\
\hline \multirow[t]{3}{*}{ log Output } & 0.178 & 0.151 & 0.141 & & & \\
\hline & $(6.68)$ & $(5.06)$ & $(1.66)$ & & & \\
\hline & $* * *$ & $* * *$ & & & & \\
\hline \multirow{4}{*}{$\begin{array}{l}\log (\text { Price of output/Price of } \\
\text { materials) }\end{array}$} & & & & 0.295 & 0.404 & -0.11 \\
\hline & & & & & & \\
\hline & & & & $(3.13)$ & $(3.01)$ & $(0.73)$ \\
\hline & & & & $* * *$ & $* * *$ & \\
\hline \multirow[t]{3}{*}{ R\&D intensity } & 0.595 & 0.779 & 0.318 & 0.495 & 0.614 & 0.317 \\
\hline & $(4.03)$ & $(3.57)$ & $(1.23)$ & $(3.11)$ & $(2.70)$ & $(1.24)$ \\
\hline & $* * *$ & $* * *$ & & $* * *$ & $* * *$ & \\
\hline \multirow[t]{4}{*}{ Intra-Industry Offshoring } & -0.083 & - & 0.635 & - & -0.014 & 0.58 \\
\hline & & 0.070 & & 0.017 & & \\
\hline & $(3.33)$ & $(2.67)$ & $(0.67)$ & $(0.69$ & $(0.58)$ & $(0.58)$ \\
\hline & $* * *$ & $* * *$ & & & & \\
\hline \multirow[t]{4}{*}{ Inter-Industry Offshoring } & -0.137 & - & 0.026 & 0.06 & 0.037 & 0.483 \\
\hline & & 0.111 & & & & \\
\hline & $(2.50)$ & $(1.97)$ & $(0.08)$ & $(1.30)$ & $(0.80)$ & $(2.28)$ \\
\hline & $* *$ & $*$ & & & & $* *$ \\
\hline \multirow[t]{4}{*}{ Constant } & -0.004 & - & 0.002 & - & -0.002 & 0.005 \\
\hline & & 0.005 & & 0.001 & & \\
\hline & $(2.28)$ & $(2.75)$ & $(0.32)$ & $(0.67)$ & $(1.17)$ & $(1.15)$ \\
\hline & $* *$ & $* * *$ & & & & \\
\hline
\end{tabular}




\begin{tabular}{l|ccc|ccc} 
Observations & 237 & 179 & 57 & 237 & 178 & 57 \\
R-squared & 0.44 & 0.43 & 0.41 & 0.41 & 0.41 & 0.35 \\
\hline
\end{tabular}

* significant at 10\%; ** significant at 5\%; *** significant at $1 \%$ 
In order to better understand the role of $R \& D$ intensity in our regressions we reestimate both labour demand models excluding R\&D intensity. When doing so intraindustry offshoring is no longer significant in the conditional model of labour demand. This probably reflects the omitted variable bias that arises when excluding R\&D intensity due to the negative correlation between $R \& D$ intensity and intra-industry offshoring. In an effort to control for technological change independent of offshoring, we gradually introduce industry and country-specific trends into our regressions. After including both country and industry-specific trends the coefficients on intra-industry and inter-industry offshoring become again statistically significant. In particular, the inclusion of industry-specific trends appears to be important. However, including trends also has a tendency to absorb the explanatory power of the other control variables.

The consequences of including industry and country-specific trends in the unconditional model of labour demand are similar in the sense that the coefficients on offshoring become increasingly negative when controlling more fully for unobserved trends. When including both industry and country-specific trends we find a weak negative effect for intra-industry offshoring on labour demand. This specification suggests that the scale effects associated with intra-industry offshoring are insufficient to completely offset the jobs lost due to its technology effect. However, the positive scale effect is still substantial. Inter-industry offshoring is positive, but statistically insignificant.

In sum, the sensitivity analysis suggests that the main results presented in the previous section are robust to the exclusion of outliers and the way one controls for technological change. The results consistently indicate that offshoring has a negative effect on employment conditional on output and no effect or a small positive effect when allowing for both scale and technology effects. Moreover, the technology effect associated with intra-industry offshoring tends to be more negative than that with inter-industry offshoring.

The analysis of offshoring presented here may be considered an extension of the analysis provided by OECD (2007b), which uses the same data but concentrates on the role of total offshoring. OECD (2007b) finds that total offshoring has a negative effect on employment conditional on output and that this is particularly important in the manufacturing sector. When using total offshoring instead of intra-industry and interindustry offshoring the results suggest no effect of offshoring on employment conditional on output and a weak positive effect on the total level of employment. The difference 
between these results and the results presented in OECD (2007b) can be attributed to differences in the way offshoring is measured, differences in the specification and differences in the sample used. Furthermore, OECD (2007b) does not find any evidence that offshoring is associated with any positive scale effects. The complete absence of scale effects cannot be easily explained on either theoretical grounds or differences in the methodology.

Table 3: Regression results over five-year differences with industry and countryspecific trends

\begin{tabular}{|c|c|c|c|c|c|c|c|c|}
\hline \multirow[b]{2}{*}{ Log (Wage/Price of materials) } & \multicolumn{4}{|c|}{ Conditional } & \multicolumn{4}{|c|}{ Unconditional } \\
\hline & -0.237 & - & - & - & - & - & - & - \\
\hline & & 0.158 & 0.093 & 0.025 & 0.406 & 0.306 & 0.287 & 0.061 \\
\hline & $(1.99)$ & $(0.89)$ & $(1.43)$ & $(0.23)$ & $(4.48)$ & $(1.74)$ & $(4.60)$ & $(0.58)$ \\
\hline & $* *$ & & & & $* * *$ & * & $* * *$ & \\
\hline \multirow[t]{3}{*}{ Log Capital stock } & 0.207 & 0.24 & 0.072 & 0.047 & 0.256 & 0.293 & 0.127 & 0.061 \\
\hline & $(2.40)$ & $(2.09)$ & $(1.37)$ & $(0.74)$ & $(2.89)$ & $(2.56)$ & $(2.00)$ & $(0.87)$ \\
\hline & $* *$ & $* *$ & & & $* * *$ & $* *$ & $* *$ & \\
\hline \multirow[t]{3}{*}{ Log Output } & 0.162 & 0.214 & 0.178 & 0.168 & & & & \\
\hline & $(3.94)$ & $(2.60)$ & $(4.39)$ & $(2.84)$ & & & & \\
\hline & $* * *$ & $* * *$ & $* * *$ & $* * *$ & & & & \\
\hline \multirow[t]{2}{*}{$\begin{array}{l}\log \text { (Price of output/Price of } \\
\text { materials) }\end{array}$} & & & & & 0.291 & 0.301 & 0.131 & 0.088 \\
\hline & & & & & $(1.23)$ & $(1.26)$ & $(0.87)$ & $(0.63)$ \\
\hline \multirow[t]{4}{*}{ Intra-Industry Offshoring } & -0.06 & - & - & - & 0.02 & - & - & - \\
\hline & & 0.048 & 0.123 & 0.117 & & 0.006 & 0.019 & 0.087 \\
\hline & $(1.54)$ & $(1.13)$ & $(2.72)$ & $(2.52)$ & $(0.64)$ & $(0.16)$ & $(0.51)$ & $(1.75)$ \\
\hline & & & $* * *$ & $* *$ & & & & $*$ \\
\hline \multirow[t]{4}{*}{ Inter-Industry Offshoring } & -0.012 & - & - & - & 0.043 & 0.028 & 0.016 & 0.018 \\
\hline & & 0.008 & 0.056 & 0.049 & & & & \\
\hline & $(0.53)$ & $(0.33)$ & $(2.15)$ & $(1.80)$ & $(2.46)$ & $(1.25)$ & $(0.83)$ & $(0.67)$ \\
\hline & & & $* *$ & $*$ & $* *$ & & & \\
\hline
\end{tabular}




\begin{tabular}{l|cccc|cccc} 
Constant & -0.003 & - & 0.006 & 0.003 & 0.000 & - & 0.014 & 0.009 \\
& & 0.012 & & & & 0.005 & & \\
& $(0.79)$ & $(1.19)$ & $(0.97)$ & $(0.27)$ & $(0.05)$ & $(0.51)$ & $(1.94)$ & $(0.79)$ \\
& & & & & & & $*$ & \\
Country dummies & No & Yes & No & Yes & No & Yes & No & Yes \\
Sector dummies & No & No & Yes & Yes & No & No & Yes & Yes \\
Observations & 238 & 238 & 238 & 238 & 238 & 238 & 238 & 238 \\
R-squared & 0.46 & 0.52 & 0.75 & 0.81 & 0.41 & 0.48 & 0.69 & 0.79 \\
\hline \hline
\end{tabular}

$*$ significant at $10 \% ; * *$ significant at $5 \% ; * * *$ significant at $1 \%$, robust $t$ statistics in parentheses 


\section{Concluding remarks}

An important element of the analysis is to explicitly account for the technology and scale effects of offshoring. To this end, we proposed a novel decomposition of sectoral employment change that allows one to identify the scale and technology effects separately and conducted a detailed econometric analysis of the scale and technology effects of offshoring for industry employment using data for 17 high income OECD countries.

The main finding in this paper is that offshoring has no effect or a slight positive effect on sectoral employment. Offshoring within the same industry ("intra-industry offshoring") reduces the labour-intensity of production, but does not affect overall industry employment. By contrast, inter-industry offshoring does not affect labour-intensity, but may have a positive effect on overall industry employment. These findings suggest that the productivity gains from offshoring are sufficiently large that the jobs created by higher sales completely offset the jobs lost by relocating certain production stages to foreign production sites.

While these findings may be striking to some they are broadly consistent with previous findings for the US by Amiti and Wei (2006), but also with Barba Navaretti and Castellani (2003) who find that establishing an affiliate abroad raises employment at home and Hanson et al. (2005) who find that an increase in the scale of affiliate production abroad raises domestic employment.

Even if offshoring typically does not result in net employment losses at the level of the industry or even the firm, this does not necessarily mean that workers do not encounter significant adjustment difficulties. OECD (2007a) shows that intra-industry offshoring is associated with increasing skill demands, suggesting that some of the workers whose jobs are lost due to the technology effect from offshoring may lack the qualifications required by the jobs created by the scale effect. A number of earlier studies have also analysed changes in the skill composition of sectoral employment associated with offshoring. Feenstra and Hanson (1996), Hijzen et al. (2005) and Ekholm and Hakkala (2006) find that offshoring may have important implications for the skill composition in an industry, although not necessarily in the same way. Whereas Feenstra and Hanson (1996) for the US and Hijzen et al. (2005) for the UK find that offshoring moves labour demand away from workers with 
low levels of skills to workers with high skill levels, Ekholm and Hakkala (2006) find that offshoring moves labour demand away from workers with intermediate levels of skills.

The offshoring data for 1995 and 2000, which are used in this study, may understate the future impact of offshoring on the sectoral and occupational composition of employment. As many have observed, advances in information and communications technologies appear to be greatly expanding the range of service activities that could be relocated to foreign production sites. It is therefore worth noting that even should offshoring come to have important implications for industry-level labour demand, this still would not imply a reduction in the total number of jobs in the economy. In this case, offshoring, like trade in final goods, would be a force for structural adjustment along the lines implied by the principle of comparative advantage. OECD (2007a) suggests that trade openness is not systematically related to aggregate employment. The extent to which increased job reallocation will be associated with temporary increases in unemployment depends for an important part on the role of institutions (Amiti and Ekholm, 2006). This constitutes a very important area for future research.

Finally, OECD (2007a) suggests that increased offshoring may not only represent a shock to which labour markets need to adjust, but may also have an impact on the way labour markets work. Rodrik (1997) hypothesised that globalisation may increase the responsiveness of employment and wages to economic shocks, by increasing the own-price elasticity of labour demand. OECD (2007a) provides new evidence that labour demand has become increasingly elastic across a number of OECD countries and that the growing practice of offshoring may have contributed to this trend. This could help to explain why workers appear to feel increasingly insecure. A more elastic labour demand would also tend to reduce the bargaining power of workers relative to employers and reduce the scope for risk-sharing arrangements between workers and firms, for example when firms provide stable wages to long-term workers, despite fluctuations in external labour market conditions. 


\begin{abstract}
ANNEX

\section{Variable Definitions}

Employment Log of total persons engaged.

Wage Log of total labour costs divided by the number of employees.

Materials Log volume of materials at 2000 constant prices.

Price of materialsLog price index of materials.

Data adjustments: For observations for which information on the price of materials was not available, the price of materials was imputed. The composition of inputs was obtained from the input-output tables. The price index of materials was imputed by multiplying the share of total purchases (domestic plus imported) by industry $\mathrm{i}$ from supplying industry $\mathrm{j}$ in total intermediate purchases (domestic plus imported) by industry $i$ with the price of value-added of industry $j$.
\end{abstract}

Capital stock Log volume of gross capital stock at 2000 constant prices.

Data adjustments: For countries for which the capital stock was not available or industry coverage was insufficient, capital stocks were reconstructed from gross fixed capital formation using a perpetualinventory method based on an assumed depreciation rate of $10 \%$. 
Output Log volume of output at 2000 constant prices.

Price of output Log price index of output.

R\&D intensity Ratio of real expenditure on research and development over real valueadded. 


\section{BIBLIOGRAPHY}

Amiti, M. and S. Wei (2005), “Fear of Service Outsourcing; Is it Justified?”, Economic Policy, 20, 308-347.

Amiti, M. and S. Wei (2006), "Service Offshoring, Productivity and Employment: Evidence from the US", CEPR Discussion Paper, No. 5475.

Amiti, M. and K. Ekholm (2006), "The Effect of Offshoring on Employment in Rigid Labor Markets: Evidence from EU Countries", mimeo.

Barba Navaretti, G. D. Castellani (2003), "Investments Abroad and Performance at Home", CEPR Discussion Paper, No. 4284.

Campa, J. and L.S. Goldberg (1997), “The Evolving External Orientation of Manufacturing Industries: Evidence from four Countries", Federal Reserve Bank of New York Economic Policy Review, Vol. 3, No. 2, pp. 53-81.

Clark, K.B. and R.B. Freeman (1980), "How Elastic is the Demand for Labor?”, Review of Economics and Statistics, Vol. 62, No. 4, pp. 509-520.

Ekholm, K. and K. Hakkala (2006), "The Effect of Offshoring on Labor Demand: Evidence from Sweden”, Scandinavian Journal of Economics, forthcoming.

European Commission (2005), Standard Eurobarometer 63: Public Opinion in the European Union, Brussels.

Feenstra, R.C. and G.H. Hanson (1996), "Globalisation, Outsourcing, and Wage Inequality", American Economic Review, Vol. 86, Iss. 2, pp. 240-245.

Feenstra, R.C. and G.H. Hanson (1999), “The Impact of Outsourcing and High-Technology Capital on Wages: Estimates for the United States, 1979-1990”, Quarterly Journal of Economics, Vol. 114, Iss. 3, pp. 907-941.

Griliches, Z. and J. Hausman (1986), "Errors in Variables in Panel Data”, Journal of Econometrics, Vol. 31, pp. 93-118.

Hamermesh, D. (1993), Labor Demand, Princeton University Press, Princeton, New Jersey. 
Hanson, G., R. Mataloni and M. Slaughter (2005), "Vertical Production Networks in Multinational Firms," Review of Economics and Statistics, November 87, pp. 664678.

Hijzen, A., H. Görg and R. Hine (2005), "International Outsourcing and the Skill Structure of Labour demand in the United Kingdom”, Economic Journal, 115, 860-878.

Hijzen, A., T. Inui and Y. Todo (2007), "Does Offshoring Pay? Firm-Level Evidence from Japan”, GEP Research Paper, 2007/14.

Hummels, D., J. Ishii, and K. Yi (2001), "The Nature and Growth of Vertical Specialisation in World Trade", Journal of International Economics, Vol. 54, pp. 75-96.

Machin, S. and J. van Reenen (1998), "Technology and Changes in Skill Structure: Evidence form Seven OECD Countries", Quarterly Journal of Economics, Vol. 113, pp. 1215-1244.

Mankiw, N.G. and P. Swagel (2006), "The Politics and the Economics of Offshore Outsourcing”, NBER Working Paper, No. 12398.

OECD (2007a), OECD Employment Outlook, Chapter 3, OECD: Paris.

OECD (2007b), Offshoring and Employment: Trends and Policy Implications, Paris, forthcoming.

Olsen, K. B. (2006), "Productivity Impacts of Offshoring and Outsourcing: A Review," OECD Science, Technology and Industry Working Papers, 2006/1, Paris.

Rodrik, D. (1997), Has globalisation gone too far?, Washington, D.C.: Institute for International Economics. 